\title{
Monitoring the Anthropogenic and Geochemical Environment Surrounding the Butana (Sudan) Drinking Water Sources Via the Determination of Heavy Metals Composition of the Soil, Streams Sediments and Gold Mining Tailings in the Wet Season (III)
}

\author{
Younis MH Younis*1, Israa M Idris ${ }^{2}$ and Abdalla A Elbashir ${ }^{3}$ \\ ${ }^{1}$ Faculty of Pharmacy, University of Medical Sciences and Technology, Sudan \\ ${ }^{2}$ Ministry of Minerals, Laboratories Department, Sudan \\ ${ }^{3}$ Chemistry Department, Faculty of Science, University of Khartoum, Sudan
}

Received: 㣋: September 22, 2018; Published:

*Corresponding author: Younis MH Younis, Faculty of Pharmacy, University of Medical Sciences and Technology, Sudan

\begin{abstract}
Further to our previous published papers on the assessment of drinking water quality status of Butana mining sites in the dry season, this current study is conducted to assess the seasonal variations in concentration of the heavy metals during the two major seasons (Dry and Wet seasons) in Butana Mining area, Eastern Sudan, aiming at unveiling the environmental pollution status of the soil, and also aiming at monitoring the anthropological and geochemical environment surroundings the sources of drinking water. To achieve this goal, 31 soil samples, 24 stream sediments and 14 gold mining tailings random sampling were analyzed for the concentration levels of the heavy metals $(\mathrm{Ni}, \mathrm{Cr}, \mathrm{Co}, \mathrm{Zn}, \mathrm{Cu}, \mathrm{Pb}, \mathrm{Cd}$, $\mathrm{Mn}, \mathrm{Fe}$ and $\mathrm{Hg}$ ) in the three sampled categories using Flame Atomic Absorption Spectrometer $5^{\text {th }}$ generation from GBC. The average concentration levels in the soil samples in Wet season were compared with those levels in the soil samples in Dry season and also compared with those average concentrations reported in most World Soils. Four different geochemical parameters were determined such as: the Enrichment Factor (EF), Geoaccumulation index (I-geo), Contamination factor (CF) and modified degree of contamination results indicated that Butana mining sediments in wet season was unpolluted (Igeo $\leq 0$ ) for $\mathrm{Ni}, \mathrm{Zn}, \mathrm{Cu}, \mathrm{Pb}$ and Fe metals, unpolluted to moderately polluted (Igeo $=0-1)$ for $\mathrm{Cr}(0.575)$, $\mathrm{Co}(0.782)$ and $\mathrm{Mn}$ (0.927), all having and strongly polluted by $\mathrm{Cd}(3.297)$ have( Igeo $=3-4)$, Enrichment factor (EF) show slight contaminated by $\mathrm{Ni}, \mathrm{Zn}, \mathrm{Cu}, \mathrm{Pb}$ and $\mathrm{Fe}$, Moderate contaminated by $\mathrm{Cr}$, Co and $\mathrm{Mn}$ and very severe contaminated by $\mathrm{Cd}$. The contamination degree (CD) calculations also showed that sediments of Butana mining area in the Wet season were very high contaminated (25.501) by anthropogenic pollution input.
\end{abstract}

Keywords: Butana Mining Area; Heavy Metals Levels; Wet season; Stream Sediment; Tailings Atomic Absorption Spectrometry; Enrichment Factor; Geo accumulation; Degree of Contamination.

Abbreviations: AMD: Acid Mine Drainage; I-geo: Geo Accumulation Index; EF: Enrichment Factor CF: Contamination Factor; CD: Contamination Degree

\section{Introduction}

The study of heavy metal deposition and accumulation is of increasing interest because of the awareness that heavy metals in water and soil may have negative consequences on human health and also on the environment. Concern over the possible ecological effect of the increasing accumulation of metallic contaminants in the environment is growing. Increased industrialization in the present and past decades has resulted in increased effluents discharged in the aquatic system. These wastes are potential sources of metals in the surrounding environment. The industrial effluents, specially, in mining tailings contain high quantities of which cause deleterious effects in the fresh water sediments and vegetations when discharged into water bodies [1]. Anthropogenic activities represent the main source of metal contamination in the environment. Moreover, pollution by heavy metals such as Copper Cu, Nickel Ni, Cadmium Cd, Zinc Zn, Chromium Cr, Mercury $\mathrm{Hg}$ and lead $\mathrm{Pb}$ is mainly due to both natural processes such as weathering of minerals and anthropogenic activities related to industry, agriculture, burning of fossil fuels, vehicular emission, all kinds of mining and metallurgical processes in addition to their unorganized waste disposal [1-5]. Heavy metal toxicity disrupts 
natural ecosystems and affects the water and food chain, leading to health problems in human and animals. Once metals are introduced into the environment, they undergo several biological and chemical processes that lead to their distribution in environmental compartments such soil, sediments and water bed [6-10].

The biochemical processes that control metal mobility and bioavailability include sorption on mineral and organic surfaces, dissolution, (bio-) mineralization, redox processes, complexation by biogenic or non biogenic ligands and the uptake by the biota [11]. These processes could determine the metal distribution in the environment and therefore their bioavailability and toxicity. Mining activity is a vital and rich source of metal contamination of ecosystems. This activity affects, relatively, small areas but could have a significant impact on the whole environment. Mine closure is predominantly being followed by abandoned piles of the gold mining tailings that are disposed onto surrounding soils leading to their exposure to environment factors. Metal release from the tailings may lead to Acid Mine Drainage (AMD), thus impacting both soil and aquatic environments [12-14]. Several studies have been undertaken on the impact of mining activity on soils, waters, sediments and plants. Additionally, concentration of trace elements in the sediment may render soils nonproductive because of phytotoxicity. Moreover, impeded litter decomposition and soil respiration are common features of heavy metals polluted soils [1]. They generally show that the most wide spread phenomenon in these sites is acid mine drainage which is due to the oxidation of metal sulfides (e.g. pyrite (FeS2)), leading to the acidification of the drainage water [12-20]. The impact of mining activity on a given site is controlled by several factors including climatic factors, mining methods, geological conditions, and of whether the mines were active or abandoned. The present investigation is a continuation of our previous published report on monitoring the anthropogenic and geochemical environment surrounding the Butana drinking water sources in the dry season. The primary objectives of the current study are to unveil the chemical composition of the soil, stream sediment and gold mines tailings in the Wet season. The secondary objectives are to carry out a comparative review of the environmental chemical variations between the Wet and Dry seasons and hence obtain basic and simple information permitting a better understanding of the anthropogenic and environmental impacts of the heavy metals and on the quality of drinking water of the Butana region, Sudan.

\section{Materials and Methods}

\section{Site Description and Soil, Stream Sediment and Tailing Sampling}

The study area is located in central Butana area within the administrative boundaries of rural Subagh locality of Gedarif State, Eastern Sudan. It comprises vast clay plains extending from the Gedarif area in the south up to latitude $-150 \mathrm{~N}$ and from the banks of the Blue Nile River in the west up to the banks of the Atbara River in the east. Climatically, the area is set within semiarid to savannah region [21] with high temperature in summer (March-June), and cold winter (December-February). The vegetation is sparse and confined to the valleys and dominated by the Acacia species (Acacia Sayal and Acacia mallifera). The rainy season in central Butana is between July and September. The raining, although, it is intermittent increases from north to south ranging from $150 \mathrm{~mm}$ to $400 \mathrm{~mm}$, and the average annual temperature in summer is around 400C (March - October) and 250Cin winter (NovemberFebruary). Soil cover of Central Butana plain is formed mainly of sticky dark clays of montomorillonitic composition, which readily swell when wet, and shrink forming wide and deep cracks when they dry up. The Butana region is located between two large water bodies (Figure 1), the Blue Nile and Atbara River; the region suffers from high seasonal variability of fresh water and this effect even the population dynamics through the seasonal movement of the livestock from South East to North West and vice versa. There are two main facilities for surface water storage in the study area, hafirs and small dams. Hafirs are very common, water from valleys (Wadies) are diverted to be stored in reservoirs (hafirs) to be used in the dry season for human water supply in addition to watering of animals.

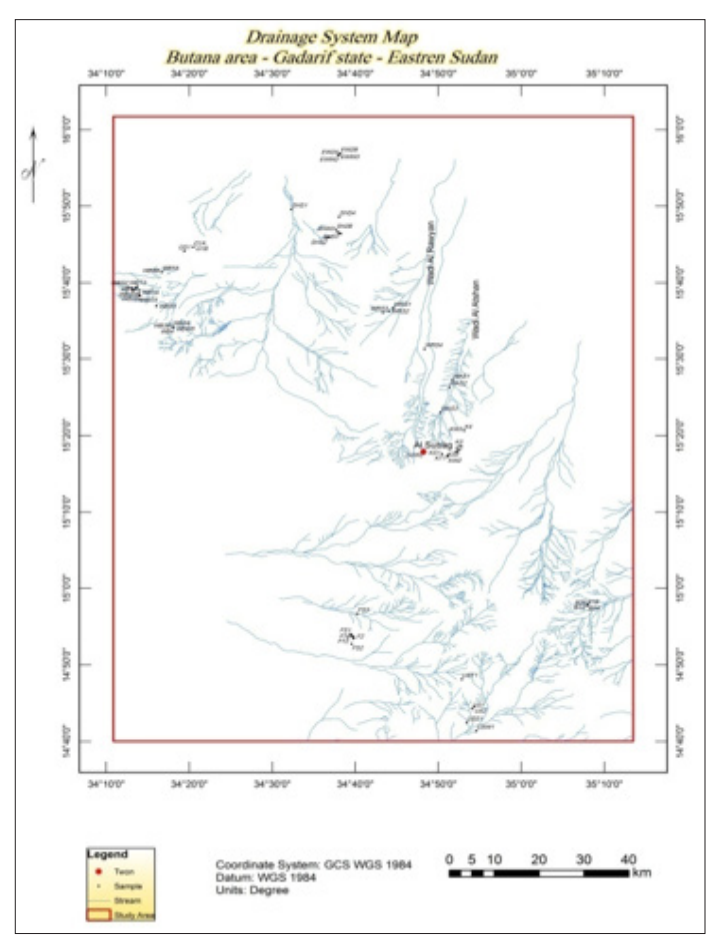

Figure 1: Rainy Water Drainage Subways Map of Study Area.

\section{Sampling Procedure}

A total of 31 soil samples, 42 stream sediments samples and 14tailings samples were collected from 8 sites in Butana mining area, Random sampling was adopted. Sampling has been done for the month of October (rainy) 2016 to authenticate the seasonal variations. At selected sampling points, samples of the soil were taken from a depth of 80 to $90 \mathrm{~cm}$ using a soil probe and the Stream sediments sampling involves digging pits to bedrocks, Then the pits were channel-sampled along the entire profile from surface to bed rock to give uniform bullock sample weigh of about $30 \mathrm{Kg}$, The pits 
are generally $40-50 \mathrm{~cm}$ deep, then all samples packed in plastic bag and transferred to the laboratory as soon as possible for analysis.

\section{Preparation of Samples and Standards}

The sample prepared in the Gras sample preparation laboratory according to the following step: the samples were air-dried $\left(25 \pm 2^{\circ} \mathrm{C}\right)$ and Primary crushing with Jaw crusher to minus $10 \mathrm{~mm}$, secondary crushing by pulverize to minus $2 \mathrm{~mm}$, splitting up to $200 \mathrm{gm}$ and Grinding by tema mill to minus 125 mesh to obtain the fine powder. For each of the heavy metals, the standard solutions were prepared by serial dilution from known standard stock solutions of $1000 \mathrm{mg} / \mathrm{L}$. A calibration curve was prepared and then the analysis of the samples for the heavy metals was performed.

\section{Determination of the Concentration Levels of Heavy Metals}

The soil, stream sediment and tailing samples after the air dried, grounded and sieved to obtain a fine powder. Conventional aqua regia digestion was performed in $250 \mathrm{ml}$ Teflon beakers. A well-mixed sample of $0.5 \mathrm{~g}$ of the sieved sediment was digested in $12 \mathrm{ml}$ of freshly prepared aqua-regia solution $(1: 3 \mathrm{HNO}-\mathrm{HCl}$, $\mathrm{v} / \mathrm{v}$ ) on a hotplate for 3 hours at $110^{\circ} \mathrm{C}$. The solution was then evaporated to near dryness. The sample was diluted with aqueous nitric acid $(20 \mathrm{ml}, 2 \%)$ and filtered through Whatman No. 42 paper into a $100 \mathrm{ml}$ volumetric flask and then diluted to $100 \mathrm{ml}$ with deionized distilled water [22]. and then the determination of heavy metals (Ni, Cr, Co, $\mathrm{Zn}, \mathrm{Cu}, \mathrm{Pb}, \mathrm{Cd}, \mathrm{Mn}, \mathrm{Fe}, \mathrm{Hg}$ ) in the samples were performed using Savant AA 5th generation AAS from GBC. The air-acetylene flame was adjusted according to the manufacturer's recommendation.

\section{Calculation of Pollution Indices}

In an attempt to understand the pattern of metal contamination in the area, useful tool was used to assessment of heavy metal pollution level in the soil sample including pollution indices such as:

a) Geo-accumulation index (I-geo),

b) enrichment factor (EF), c) contamination factor (Cf) and iv) contamination degree (Cd) of sampling sites were used to calculate heavy metal concentration in soil of Butana mining area.

\section{Geoaccumulation Index}

Geo-accumulation index serves to assess contamination by comparing current and pre-industrial concentration of heavy metals [23]. Background concentration of heavy metals in earth's crust was used as reference value implicating pre-industrial environment. I geo is calculated through the following equation:

I-geo $=\log 2\left[\mathrm{C}_{\mathrm{n}} / 1.5 \mathrm{~B}_{\mathrm{n}}\right]$.

Where $C_{n}$ is concentration of element $n$ in the soil sample and $B_{n}$ is geochemical; background value. The background value provided by [24], were used to calculate the index of geoaccumulation. The constant 1.5 helps to analyze natural fluctuation between the content of a given substance in environment and very small anthropogenic influences. The geoaccumulation index scale consists of seven grades (0-6) ranging from unpolluted to extremely polluted (Table 1).

Table 1: Muller's Classification for Geoaccumulation index (Igeo) scale.

\begin{tabular}{|c|c|c|}
\hline Class & Igeo Value & Soil Quality \\
\hline 0 & 0 & Unpolluted \\
\hline 1 & $0-1$ & From unpolluted to moderately polluted \\
\hline 2 & $1-2$ & Moderately polluted \\
\hline 3 & $2-3$ & From moderately polluted to strongly polluted \\
\hline 4 & $3-4$ & Strongly polluted \\
\hline 5 & $4-5$ & From strongly polluted to extremely polluted \\
\hline 6 & $>5$ & Extremely polluted \\
\hline
\end{tabular}

\section{Enrichment Factor}

The Enrichment Factor (EF) is established on the basis of standardization of a tested element a against a reference one. A reference element is the one characterized by low occurrence variability such as $\mathrm{Al}, \mathrm{Fe}$ or $\mathrm{Zn}$, in this study iron was used as a conservative tracer to differentiate natural from anthropogenic components.

Table 2: Categories of Enrichment factor [28], Contamination factor (CF) and contamination degree (Cd) categories.

\begin{tabular}{|c|c|c|c|c|}
\hline \multicolumn{1}{|c|}{ EF Value } & Category & CF Classes & CF and CD Categories & \multicolumn{2}{c|}{ CD classes } \\
\hline$<2$ & Deficiency & $\mathrm{CF}<1$ & Low CF indicating low contamination $/ \mathrm{Low} \mathrm{Cd}$ & $6 \leq 6$ \\
\hline $2-5$ & Moderate & $1 \leq \mathrm{CF}<3$ & Moderate $\mathrm{CF} / \mathrm{Cd}$ & $6 \leq \mathrm{Cd}<12$ \\
\hline $5-20$ & Significant & $3 \leq \mathrm{CF}<6$ & Considerable $\mathrm{CF} / \mathrm{Cd}$ & $12 \leq \mathrm{Cd}<24$ \\
\hline $20-40$ & Very High & $\mathrm{CF} \geq 6$ & Very high CF $/ \mathrm{Cd}$ & $\mathrm{Cd} \geq 24$ \\
\hline
\end{tabular}

Enrichment factor EF of heavy metals (Table 2) was calculated as the ratio of elemental concentration of sediment normalized to Fe [25]

$$
(\mathrm{Cn} / \mathrm{Fe}) \text { sediment / }(\mathrm{Cn} / \mathrm{Fe}) \text { reference }
$$

Where $C_{n}$ is the concentration of the examined element ' $n$ ' in the surface sediments, Fe as the reference element and as a conservative tracer to differentiate natural from anthropogenic components, Five contamination categories are recognized on the basis of the enrichment factor [26] as present in Table 2 .

\section{Contamination factor}

The assessment of the soil contamination was also carried out using contamination factor and contamination degree. The contamination factor described as a ratio of the concentration of the element in samples to the pre-industrial reference value for the element and was calculated using the relation described by [27].

$$
C f=C n / B n
$$


In the above formulas, $\mathrm{Cn}$ is the concentration of the examined element ' $n$ ' in the surface sediments and $B n$ is the geochemical background concentration of metal ' $n$ '. Four categories of contamination factor were described by [27] as given in Table 2 .

\section{Degree of Contamination}

Degree of contamination (Cd) defined as the sum of all contaminant factor values of the heavy metals. The categories was described in Table 2. The sum of all contamination factors (Cf)

Statistical Analysis: SPSS statistics 24 was used for data analysis.

\section{Results and Discussion}

Butana encompasses vast tracts of agriculture land supported by huge animal's wealth. The presence of mines in this area will lead to contamination the soil by heavy metals and metalloids and will have impact in agriculture and plant (grass) beds and hence affect animal wealth. A number of metals including chromium, iron, zinc, cadmium, mercury and copper are known to significantly, compromise the quality of soil and cause adverse effects to human and animal health. Very high or low concentrations of some of these heavy metals may have inhibitory properties to plant growth. Presumably determination of the degree of contamination is essential. The results of chemical analysis carried out in soil of the Butana mining area where heavy metals pollution was observed is shown in Table 3 presents the maximum, minimum and mean concentration levels of the 10 heavy metals in the surrounding soil, stream sediment and gold mining tailings of the study area during the Wet Season, Generally higher concentration of heavy metals was observed in all samples was found in wet season followed by dry season (Figure 1). Among all the heavy metals detected in sample during the wet season, the heaps of tailings (gold mining wastes) have shown the highest concentration levels of mercury $24.01 \mathrm{mg} \mathrm{kg}^{-1}$, iron $89,310 \mathrm{mg} \mathrm{kg}^{-1}$ (which is approximately twice its concentration of iron in dry season $42,649 \mathrm{mg} \mathrm{kg}^{-1}$ ), lead $1039.0 \mathrm{mg} \mathrm{kg}^{-1}$, Zinc $370.08 \mathrm{mg} \mathrm{kg}^{-1}$ and Cobalt $71.46 \mathrm{mg} \mathrm{kg}^{-1}$, and this concentration level in wet season is highest than concentration levels of heavy metals in dry season (mercury $20.54 \mathrm{mg} \mathrm{kg}^{-1}$, iron 25,916 $\mathrm{mg} \mathrm{kg}^{-1}$, lead $1015.90 \mathrm{mg} \mathrm{kg}^{-1}$, Zinc $266.29 \mathrm{mg} \mathrm{kg}^{-1}$ and Co19.20 mg kg-1 ) [29].

Table 3: Heavy Metals Levels in the Soil, Stream Sediment in and Gold Mines Tailings in Wet season Comparison with reported levels in Most World Soil MWS [30].

\begin{tabular}{|c|c|c|c|c|c|c|c|c|c|c|c|c|}
\hline \multirow{2}{*}{ Season } & \multirow{2}{*}{$\begin{array}{l}\text { Type of } \\
\text { Samples }\end{array}$} & & \multicolumn{10}{|c|}{ Average Concentration of Elements } \\
\hline & & & $\mathrm{Ni}$ & $\mathrm{Cr}$ & Co & $\mathrm{Zn}$ & $\mathrm{Cu}$ & $\mathbf{P b}$ & Cd & Mn & $\mathrm{Fe}$ & $\mathrm{Hg}$ \\
\hline \multirow{9}{*}{ Wet } & \multirow{3}{*}{ Soil } & Max & 67.65 & 172.9 & 78 & 168.75 & 1573.9 & 112.73 & 48.96 & 2185 & 100,290 & 10.34 \\
\hline & & Min & 1.85 & 14.05 & 9.21 & 5.19 & 7.46 & 21.75 & 1.89 & 13.83 & $3,091.00$ & 8.75 \\
\hline & & Mean & 34.75 & 93.475 & 43.6 & 86.97 & 790.6 & 67.24 & 25.42 & 1099.4 & 51,690 & 9.545 \\
\hline & \multirow{3}{*}{$\begin{array}{c}\text { Stream } \\
\text { sediment }\end{array}$} & Max & 114.63 & 395.03 & 60.13 & 97.25 & 89.31 & 137.1 & 26.38 & 5112 & $40,517.60$ & 12.05 \\
\hline & & Min & 95.53 & 52 & 43.02 & 19.05 & 25.03 & 36.25 & 3.1 & 878.13 & $18,371.00$ & 11.67 \\
\hline & & Mean & 105 & 223.51 & 51.57 & 58.15 & 57.17 & 86.67 & 14.74 & 2995 & $29,444.00$ & 11.86 \\
\hline & \multirow{3}{*}{ Tailings } & Max & 65.5 & 167.5 & 110.34 & 734 & 596.3 & 2039.1 & 10.57 & 812.58 & 45.162 .0 & 28.93 \\
\hline & & Min & 15.35 & 15.06 & 32.58 & 6.17 & 17.89 & 39.21 & 2.39 & 67.3 & $89,310.00$ & 19.1 \\
\hline & & Mean & 40.42 & 91.28 & 71.46 & 370.08 & 307 & 1039 & 6.48 & 439.94 & $89,310.00$ & 24.01 \\
\hline
\end{tabular}

The concentration level of mercury in the Tailings has been found to be two folds of its concentration level in either the Soil or Stream Sediments. The soil surroundings have shown the highest concentration levels of copper $790.6 \mathrm{mg} \mathrm{kg}^{-1}$ and Cadmium $25.42 \mathrm{mg}$ $\mathrm{kg}^{-1}$. Nickel $105.0 \mathrm{mg} \mathrm{kg}^{-1}$, Chromium223.51 $\mathrm{mg} \mathrm{kg}^{-1}$ and Manganese $2995.0 \mathrm{mg} \mathrm{kg}^{-1}$ it has also been shown that highest concentrations level in sediment. It could also be noticed from Table that the order of increasing concentration level of $\mathrm{Cr}$ and $\mathrm{Mn}$ could be in the sequence: stream sediment $>$ soil $>$ tailing. Ni concentration could be increasing in the sequence: stream sediment $>$ tailing $>$ soil. Co, $\mathrm{Pb}$ and $\mathrm{Hg}$ were rated as Tailing $>$ Stream Sediment $>$ Soil samples, $\mathrm{Zn}$ and $\mathrm{Fe}$ are rated as: tailing $>$ soil $>$ stream sediment samples. $\mathrm{Cd}$ is rated in the sequence: soil $>$ stream sediment $>$ tailings. The $\mathrm{Cu}$ concentration level is rated in the sequence: Soil $>$ Tailings $>$ Stream sediment samples. Mean concentration of Cobalt, Zinc, Copper, lead and Cadmium concentrations in all sites of the Butana region are extremely higher than it is reported in the World Common Soil (Table 4).
Table 4: Heavy Metals Concentration Levels in Most World Soil MWS Quality Guidelines.

\begin{tabular}{|c|c|c|}
\hline Element & Common Range in Soils & Canadian Soil Quality \\
\hline $\mathrm{Cd}$ & 00.06 & 1.4 \\
\hline $\mathrm{Cr}$ & 100.00 & 64 \\
\hline $\mathrm{Co}$ & 08.00 & 40 \\
\hline $\mathrm{Cu}$ & 30.00 & 63 \\
\hline $\mathrm{Ni}$ & 40.00 & 50 \\
\hline $\mathrm{Pb}$ & 10.00 & 70 \\
\hline $\mathrm{Zn}$ & 50.00 & 200 \\
\hline
\end{tabular}

The concentration of Nickel in stream sediments and tailings, the concentration of Chromium in stream sediment samples, the concentration of Manganese in soil and stream sediment and the concentration of iron in soil and tailing samples are in levels extremely higher than concentration in Most World Common Soil. Compared to Canadian Soil Quality Guidelines (Table 4), it 
was observed that the concentration of chromium, Cadmium and Cobalt in soil, stream sediment and tailing samples of Butana region is extremely higher than that reported in the Canadian soil Quality Guidelines (Table 4). It was also being observed that the Nickel in stream sediment, the concentration of Zinc in tailing, the concentration level of Copper in soil and tailing and concentration of lead in stream and tailing samples were above its concentration in Canadian Soil Quality Guidelines.

To make a comprehensive assessment of soil contamination, some geochemical parameters were applied such as Geoaccumulation index (Igeo), enrichment factor EF, and contamination factor $\mathrm{CF}$ and contamination degree CD. For example, the Geoaccumulation was used to calculate metal contamination level in the soils in wet and dry season (Table 5), the calculated Igeo for the sediment samples indicated that the sediment in Butana mining area in wet season was unpolluted, with values for $\mathrm{Ni}, \mathrm{Zn}, \mathrm{Cu}, \mathrm{Pb}$ and Fe metals Igeo $\leq 0$ (Table 1 ), unpolluted to moderately polluted' or enriched for $\mathrm{Cr}$ (0.575), Co (0.782) and Mn (0.927), all having Igeo $=0-1$ and strongly polluted by $\mathrm{Cd}$ (3.297) have Igeo = 3-4. when compare the calculated Igeo for the sediment sample in wet season with calculated Igeo for the sediment sample during the dry season [29], We found on the basis of the mean values of Igeo the calculated values of Igeo in the wet season is above the calculated values in dry season, and the Butana sediment in wet and dry season is greatly enriched with the following heavy metals in the order: $\mathrm{Cd}>\mathrm{Mn}>\mathrm{Co}$ $>$ Cr (Figure 2).

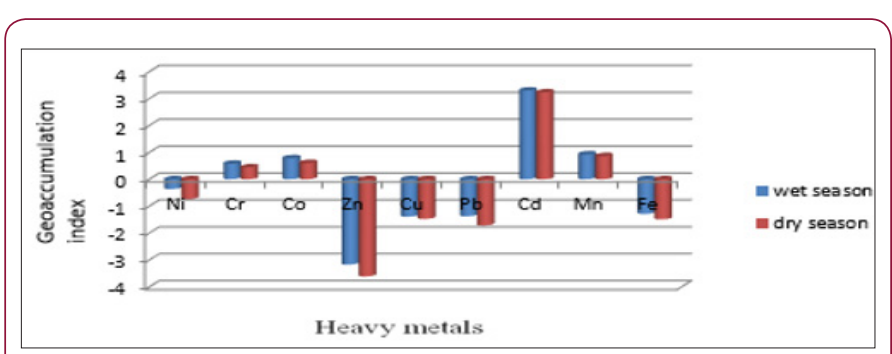

Figure 2: Geo accumulation index values of the heavy metals in sediments of Butana mining area in wet and dry seasons.

Table 5: Heavy Metals Concentration Levels in Most World Soil MWS Quality Guidelines.

\begin{tabular}{|c|c|c|c|c|c|c|c|c|c|c|}
\hline Elements & Season & $\mathbf{N i}$ & $\mathbf{C r}$ & $\mathbf{C o}$ & $\mathbf{Z n}$ & $\mathbf{C u}$ & $\mathbf{P b}$ & $\mathbf{C d}$ & $\mathbf{M n}$ & $\mathbf{F e}$ \\
\hline \multirow{2}{*}{ I-geo } & wet & -0.363 & 0.575 & 0.782 & -3.174 & -1.392 & -1.376 & 3.297 & 0.927 & -1.29 \\
\cline { 2 - 23 } & dry & -0.734 & 0.445 & 0.605 & -3.612 & -1.475 & -1.713 & 3.232 & 0.861 & -1.49 \\
\hline
\end{tabular}

The Enrichment Factor (EF) can be used to differentiate between the metals originating from anthropogenic activities and those from natural sources. The results of the calculated EF values of heavy metals in the sediment samples of Butana mining area during the wet season (Table 6) enriched for metals in the following order are $\mathrm{Cd}(23.00)>\mathrm{Mn}(4.45)>\mathrm{Co}(4.023)>\mathrm{Cr}(3.48)>\mathrm{Ni}$ (1.82) $>\mathrm{Fe} \mathrm{(1.0)} \mathrm{>} \mathrm{Pb}(0.901)>\mathrm{Cu}(0.892)>\mathrm{Zn}(0.259)$ respectively and this indicate that the stream sediment of butana mining area in wet season were slight contaminated by $\mathrm{Ni}, \mathrm{Zn}, \mathrm{Cu}, \mathrm{pb}$ and $\mathrm{Fe}$, Moderate contaminated by $\mathrm{Cr}$, Co and $\mathrm{Mn}$ and very severe by $\mathrm{Cd}$. When compare the results of the calculated EF values of heavy metals in wet season with calculated EF values of heavy metals in dry season of the sediment samples of Butana mining area we found the $\mathrm{EF}$ values $\mathrm{O} \mathrm{Cr}, \mathrm{Co}, \mathrm{Cu}, \mathrm{Pb}, \mathrm{Cd}$ and $\mathrm{Mn}$ in the wet season is below the EF values in dry season, and the EF values in wet season enriched for metals in the following order, $\mathrm{Cd}>\mathrm{Mn}>\mathrm{Co}>\mathrm{Cr}>$ $\mathrm{Ni}>\mathrm{Fe}>\mathrm{Pb}>\mathrm{Cu}>\mathrm{Zn}$ respectively, and in dry season enriched in the following order, $\mathrm{Cd}>\mathrm{Mn}>\mathrm{Co}>\mathrm{Cr}>\mathrm{Pb}>\mathrm{Zn}>\mathrm{Ni}>\mathrm{Cu}>\mathrm{Fe}$ respectively (Figure 3).

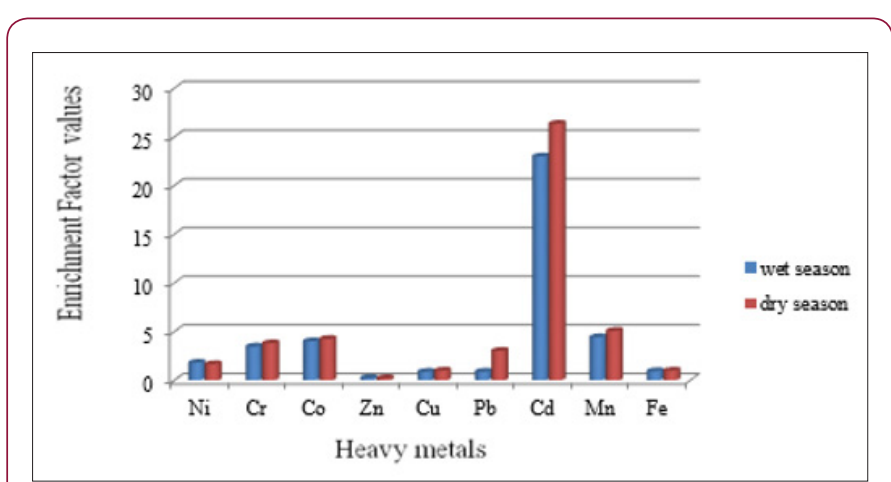

Figure 3: Enrichment Factor values of the heavy metals in sediments of Butana mining area in wet and dry season.

Table 6: Enrichment Factor values of the heavy metals in sediments of Butana mining area in wet and dry seasons.

\begin{tabular}{|c|c|c|c|c|c|c|c|c|c|c|}
\hline Elements & Season & Ni & Cr & Co & Zn & Cu & Pb & Cd & Mn & Fe \\
\hline \multirow{2}{*}{ EF } & wet & 1.82 & 3.487 & 4.023 & 0.259 & 0.892 & 0.901 & 23 & 4.45 & 01.00 \\
\cline { 2 - 25 } & dry & 1.68 & 3.82 & 4.27 & 0.229 & 1.01 & 3.04 & 26.37 & 5.10 & 01.00 \\
\hline
\end{tabular}

The results of Contamination Factor and Contamination degree of Butana mining area in Table 7 indicates that the sediments of butana mining area in wet season were low contaminated for $\mathrm{Zn} \mathrm{(0.166),} \mathrm{Cu}$ (0.571), $\mathrm{Pb}(0.577)$ and $\mathrm{Fe}$ (0.613), Moderate contaminated for Ni (1.166), Cr (2.235), Co (2.578) and Mn (2.852) and very high contaminated for Cd (14.74) of heavy metals in Butana mining area we found the sediments of Butana area were low contaminated for $\mathrm{Ni}(0.90), \mathrm{Zn}$ (0.122), (0.641), $\mathrm{Cu}(0.54)$ and Fe (0.53), Moderate contaminated for $\mathrm{Cr}$ (2.04), Co (2.28), $\mathrm{Pb}$ (1.63) and Mn (2.72), considerable contaminated for Co (5.705) and very high contaminated for Cd (14.09) (Figure 4). The results of contamination degree (Cd) showed that sediments of Butana mining area in wet season was very high contaminated (25.501) by anthropogenic pollution input, and this value is higher than contamination degree in sediment of Butana mining area in dry season (24.852). 
Table 7: (CF) and (CD) of the heavy metals in sediments of Butana mining area in wet and dry season.

\begin{tabular}{|c|c|c|c|c|c|c|c|c|c|c|c|}
\hline Element & season & $\mathbf{N i}$ & $\mathbf{C r}$ & $\mathbf{C o}$ & $\mathbf{Z n}$ & $\mathbf{C u}$ & $\mathbf{P b}$ & $\mathbf{C d}$ & $\mathbf{M n}$ & $\mathbf{F e}$ & $\mathbf{C d}$ \\
\hline \multirow{2}{*}{ CF } & wet & 1.166 & 2.235 & 2.578 & 0.166 & 0.571 & 0.577 & 14.740 & 2.852 & 0.613 & 25.5017 \\
\cline { 2 - 30 } & dry & 0.90 & 2.04 & 2.28 & 0.122 & 0.54 & 1.63 & 14.09 & 2.72 & 0.53 \\
\hline
\end{tabular}

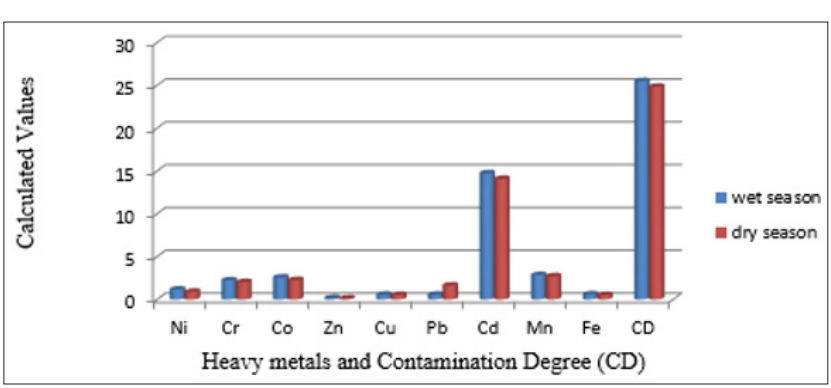

Figure 4: Histogram of the Contamination factor $(\mathrm{CF})$ and contamination degree (CD) of the heavy metals in sediments of Butana mining area in wet and dry season.

\section{Conclusion and Recommendations}

It is concluded that this study, the pollution status in Butana mining area would not stay static, as mining activity continuous, more pollution was emerging; even with mining activity finished, tailing waste could be carried away by rainy, underground water streams, Moreover the state of heavy metals within soil would change with soil condition, and soluble heavy metals would move with water migrations. It could also be, generally, concluded that the primary influencing factor of Butana drinking water pollution is actually anthropogenic related to the heavy and unorganized gold mining public activities leading to pollution of water with hazardous minerals such as mercury, cadmium, lead and chromium. Natural influencing factors, not to be ignored, are also prevailing due to the richness of the Butana region with various kinds of heavy metals such as gold, iron, cobalt, nickel, zinc and manganese.

The former and latter factors were also being confirmed by the results obtained from the mineral composition of the surrounding soils stream sediments as well. Further confirmations were attained from the determination of the geochemical parameters: Geoaccumulation index Igeo, contamination factor CF enrichment factor $\mathrm{EF}$ and contamination degree $\mathrm{Cd}$, whose values were pertinent with the analytical results obtained in the present study. Induced pollution can pose serious threats to water, soil, flora, fauna and undoubtedly human health of the area nearest to Butana mine sites. This study recommended an immediate plan for mitigation and remediation the Butana area

\section{Acknowledgement}

Our thanks are due to the Ministry of minerals -Geological Research Authority (GRAS) for funding the research project. Thanks, are also due to The State of Gedarif local Government Office for facilitating the tours around the sites in which the work has been carried out. Our thanks and gratitude is due to the University of Medical Sciences and Technology and University of Khartoum for the supervision of this research project.

\section{References}

1. Fangueiro D, Bermand A, Santos E, Carapuca H, Duarte A (2002) Heavy Metal Mobility Assessment In Sediments Based On A Kinetic Approach of the Edta Extraction: Search For Optimal Experimental Conditions Anal Chim Acta 459: 245.Achudume AC and Odo S Pollution Status and Effect of Crude Oil Spillage in Ughoton Stream Ecosystem in Niger Delta. Journal of Ecology and The Natural Environment 3: 469-473.

2. Sandroni V, Smith CM (2002) Microwave digestion of sediment, soils and urban particulate matter for trace metal analysis. Talanta 60(4): 715723.

3. Cobello Carcia A, Prego R, labanderia A (2003) Water Research 38: 1753.

4. Maas S, Scheifler R, Benslama M (2010) Spatial distribution of heavy metal concentrations in urban, Surburban and agriculture soils in a Mediterranean city of Algeria. Environmental pollution 158(6): 22942301.

5. Adriano DC (1986) Trace elements in the terrestrial environment. Berlin Heidelberg New York: Springer.

6. Misra V, Jaffery FN, Viswanathan PN (1994) Risk assessment of water pollutants. Environmental Monitoring and Assesstment 29(1): 29-40.

7. Herreweghe SV, Swennen R, Cappuyns V, Vandecasteele C (2002) Chemical associations of heavy metals and metalloids in contaminated soils near former ore treatment plants: A differentiated approach with emphasis on $\mathrm{p}^{\mathrm{H}}$ stat-leaching. Journal of Geochemical Exploration 76(2): 113-138.

8. Jung MC, Thornton I, Chon HT (2002) Arsenic, Sb and Bi contamination of soils, plants, waters and sediments in the vicinity of the Dalsung $\mathrm{Cu}-\mathrm{W}$ mine in Korea. Science of the Total Environment 295(1): 81-89.

9. Liu WX, Coveney RM, Chen JL (2003) Environmental quality assessment on a river system polluted by mining activities. Applied Geochemistry 18(5): 749-764.

10. Tahiri M, Benyaïch F, Bounakhla M, Bilal E Gruffat JJ, Moutte J, et al. (2005) Multivariate analysis of heavy metal contents in soils, sediments and water in the region of Meknes (central Morocco). Environmental Monitoring Assessment 102(3): 405-417.

11. Kraemer SM, Hering JG (2004) Biogeochemical controls on the mobility and bioavailability of metals in soils and groundwater. Aquatic Sciences 66: $1-2$.

12. Salomons W (1995) Environmental impact of metals derived from mining activities: Processes, predictions, prevention. Journal of Geochemical Exploration 52(1): 5-23.

13. Passariello B, Giuliano V, Quaresima S, Barbaro M, Caroli S, et al. (2002) Evaluation of environmental contamination at an abandoned mining site. Microchemical Journal 73(1): 245- 250.

14. Mian MH, Yanful EK (2003) Tailings erosion and resuspension in two mine tailings ponds due to wind waves. Advances in Environmental Research 7(4): 745-765.

15. Bell FG, Bullock SET, Hälbich TFJ, Lindsay P (2001) Environmental impacts associated with an abandoned mine in the Witbank Coalfield, South Africa. International Journal of Coal Geology 45(2): 195-216.

16. Baker BJ, Banfield JF (2003) Microbial communities in acid mine drainage. FEMS Microbiology Ecology 44(2): 139-152.

17. El Gharmali A, Rada A, El Adnani M, Tahlil N, El Meray (2004) Impact of acid mining drainage on the quality of superficial waters and sediment 
in the Marrakech region, Morocco. Environment \& Technology 25(12): 1431-1442.

18. Lee JY, Choi JC, Lee KK (2005) Variation in heavy metal contamination of stream water and groundwater affected by an abandoned lead-zinc mine in Korea. Environmental Geochemistry and Health 27(3): 237-257.

19. Boularbah A, Schwartz C, Bitton G, Morel JL (2006) Heavy metal contamination from mining sites in South Morocco: 1. Use of a biotest to assess metal toxicity of tailings and soils. Chemosphere 63(5): 802-810.

20. Boularbah A, Schwartz C, Bitton G Aboudrar W, Ouhammou A, (2006) Heavy metal contamination from mining sites in South Morocco: 2. Assessment of metal accumulation and toxicity in plants. Chemosphere 63(5): 811-817.

21. Van Der Kevie W (1973) Climate Zones in the Sudan. Soil Survey Department Wad medani.

22. Chen M, LQ Ma (2001) Comparison of aqua-reqia methods for 20 Florida soils. Soil sci soc Am J 65(2): 491-499

23. Müller G (1969) Index of geoaccumulation in sediments of the Rhine River. Geo journal 2: 108-118.

\section{ISSN: 2574-1241}

DOI: 10.26717/BJSTR.2018.09.001821

Younis MH Younis. Biomed J Sci \& Tech Res

(C) This work is licensed under Creative

Submission Link: https://biomedres.us/submit-manuscript.php
24. Liao G, Chao W (2004) Assessment of heavy metallic ions pollution for a river near a metal mine. J Mining and Metallurgy 13(1): 86-90.

25. Müller G (1981 The heavy metal pollution of the sediments of the Neckar and its tributaries. Chemist newspaper 6:157- 64 .

26. Faiz Y, Tufail M, Javed MT, Chaudhary T, Siddique N (2009) Road dust Pollution of $\mathrm{Cd}, \mathrm{Cu}, \mathrm{Ni}, \mathrm{Pb}$ and $\mathrm{Zn}$ along Islamabad Expressway. Pakistan. Micro Chem J 92(2): 186-192.

27. Hakanson L (1980) An ecological risk index for aquatic pollution control. A sedimentological approach. Water Res 14(8): 975-1001.

28. Sutherland RA (2000) Bed sediment-associated trace metals in an urban stream, Oahu, Hawaii. Environmental Geology 39(6): 611-627.

29. Issra M Idris, Younis MH Younis, Abedalla M Elbashir (2018) Monitoring the Anthropogenic and Geochemical Environment Surrounding the Butana Drinking Water Sources via the Determination of Heavy Metals Composition of the Soil, Streams Sediments and Gold Mining Tailings (II) European Interntional Journal of Science and Technology.

30. Lindsay WL (1979) Chemical Equilibria in Soils. (1 ${ }^{\text {st }}$ Edition), John Wiley and Sons, New York, USA, p. 449.

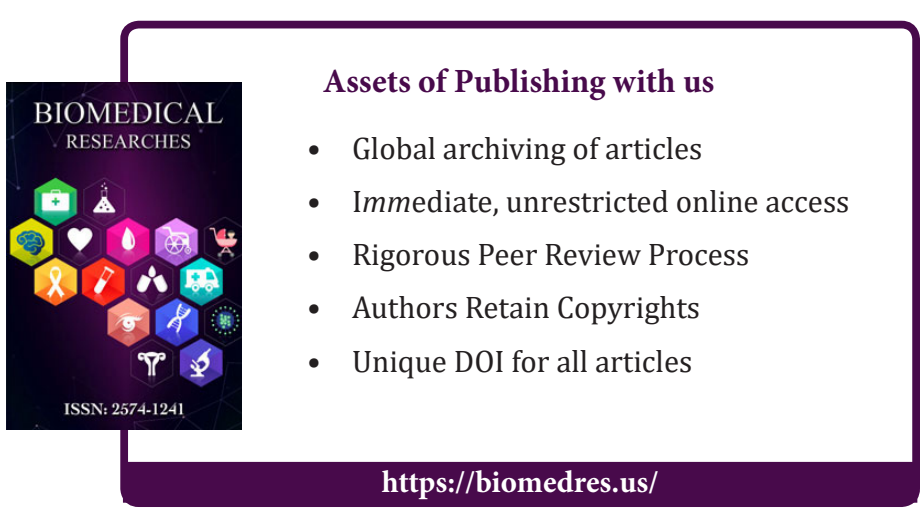

